REGARDS

SUR L'ECONOMIE ALLEMAND

BULLETIN ECONOMIQUE DU CIRAC
Regards sur l'économie allemande

Bulletin économique du CIRAC

$83 \mid 2007$

Varia

\title{
Commerce de détail : pas de pessimisme
}

\section{Solène Hazouard}

\section{OpenEdition}

Journals

Édition électronique

URL : http://journals.openedition.org/rea/605

DOI : $10.4000 /$ rea. 605

ISBN : 978-2-8218-0862-1

ISSN : 1965-0787

Éditeur

CIRAC

Édition imprimée

Date de publication : 1 octobre 2007

Pagination : 38

ISSN : 1156-8992

Référence électronique

Solène Hazouard, "Commerce de détail : pas de pessimisme », Regards sur l'économie allemande [En ligne], 83 l octobre 2007, document 3, mis en ligne le 01 octobre 2009, consulté le 15 septembre 2020. URL : http://journals.openedition.org/rea/605

Ce document a été généré automatiquement le 15 septembre 2020.

(C) CIRAC 


\title{
Commerce de détail : pas de pessimisme
}

\author{
Solène Hazouard
}

1 Malgré un recul de l'indice de confiance des consommateurs (indice GfK) à la fin septembre pour la seconde fois consécutive, la Fédération allemande du commerce de détail (HDE) reste optimiste quant à l'évolution du CA de la branche (hors automobile). En 2007, il devrait s'établir à 394 milliards $€$ (soit 2 milliards $€$ seulement de plus qu'en 2006). Certes, selon la dernière enquête réalisée par la HDE, $41 \%$ des entreprises du commerce de détail avaient vu reculer leur CA au premier semestre. Mais cette baisse est normale, et ne concerne que certains types de biens : fin 2006, les Allemands avaient puisé dans leurs économies pour s'équiper en biens d'ameublement et en produits électroniques, principaux secteurs en recul depuis. Et l'approche de la période de Noël devrait compenser ce recul. La stagnation relative du commerce de détail a des causes plus structurelles que conjoncturelles ou fiscales.

2 Les commerçants, en effet, ne redoutent plus tant 'l'effet TVA' que la détérioration de l'environnement réservé aux activités des PME. Alors qu'en 2006, la TVA était leur principal sujet de préoccupation ( $67 \%$ des sondés), elle les inquiète beaucoup moins aujourd'hui (41\% seulement) que l'évolution des conditions-cadre réservées à l'activité (51\% des réponses contre $48 \%$ en 2006) ou le risque de perte d'attractivité des commerces en centre-ville ( $43 \%$ contre $34 \%$ l'an dernier). Ces incertitudes concernent la nouvelle fiscalité des entreprises (la réforme est en cours), l'issue des négociations avec le syndicat des services Ver.di, rendues particulièrement difficiles par la libéralisation des horaires d'ouverture des magasins (voir REA 79/06) et la tendance à la concentration observée dans un secteur où, déjà, cinq distributeurs se partagent $70 \%$ du marché. 
INDEX

Mots-clés : commerce 